\title{
Effect of n-butanol/diesel blends on performance, emission, noise and vibration characteristics of a diesel engine generator
}

\author{
Walid Helmy ${ }^{\text {a }}$, Ismail Youssef ${ }^{b}$, Mohammad Mourad ${ }^{b}$, Ali El-Tawwab ${ }^{b}$ \\ a PhD Student, walidhelmy1802@gmail.com Corresponding author \\ ${ }^{\mathrm{b}}$ Automotive Engineering Department, Faculty of Engineering, Minia University, Egypt \\ e-mails; ism22@hotmail.com- m.mourad@mu.edu.eg-ali tawwab@hotmail.com
}

\begin{abstract}
Simple diesel engine generators in general are noisy and pollute air. It is urgently needed to find alternative fuels applicable for new as well as old engines without structural modifications and along with keeping the environment clean. Diesel-alcohol blends could be such alternatives fuels. For that purpose, in this study tests were carried out using diesel fuel first then, were carried out using three of n-butanol/diesel blends on volume bases with n-butanol concentrations of 5,10 and $15 \%$, identified as $\mathrm{nBu} 5, \mathrm{nBu} 10$ and $\mathrm{nBu} 15$. The engine under study is a single cylinder, four stroke, air cooled diesel engine generator and the tests have been carried out at a fixed $3000 \mathrm{rpm}$ and five different load conditions without any hardware modifications. Total noise, engine block vibration, NOx, HC, CO, BSFC, BTE and EGT have been observed of diesel and n-butanol/diesel blends. The following conclusions can be drawn with nbutanol/diesel fuel blends against diesel fuel; (i) According to engine performance test results; a little higher specific fuel consumption was observed with corresponding slight increase of brake thermal efficiency and little lower exhaust gas temperatures. (ii) According to engine emission test results; the NOx was slightly reduced, this reduction being higher the higher the percentage of butanol in the blend. The $\mathrm{CO}$ emissions were reduced, on the contrary, $\mathrm{HC}$ emissions were increased, this increase being higher the higher the percentage of butanol in the blend. According to engine vibration and noise test results; Noise and vibration characteristics are somewhat better especially at lesser loads.
\end{abstract}


Keywords; Butanol-diesel blend. Engine Performance. Vibration. Noise. Diesel engine generator.

\section{Nomenclature}

\begin{tabular}{|c|c|}
\hline ASTM & American society for testing and materials \\
\hline DF & Diesel \\
\hline B & Biodiesel \\
\hline $\mathrm{nBu}$ & n-butanol \\
\hline D100 & $100 \%$ diesel fuel \\
\hline nBu5 & $5 \%$ n-butanol with $95 \%$ reference diesel \\
\hline nBu10 & $10 \%$ n-butanol with $90 \%$ reference diesel \\
\hline nBu15 & $15 \%$ n-butanol with $85 \%$ reference diesel \\
\hline $\mathrm{DF} / \mathrm{nBu}_{5,10,15}$ & Diesel/5, 10 and $15 \%$ n-butanol blends \\
\hline BSFC & Brake specific fuel consumption (g/kW h) \\
\hline BTE & Brake thermal efficiency $(\%)$ \\
\hline $\mathrm{CN}$ & Cetane number \\
\hline $\mathrm{CO}$ & Carbon monoxide (\% volume) \\
\hline $\mathrm{CO} 2$ & Carbon dioxide (\% volume) \\
\hline $\mathrm{CV}$ & Calorific value $(\mathrm{kJ} / \mathrm{kg})$ \\
\hline EGT & Exhaust gas temperature $\left({ }^{\circ} \mathrm{C}\right)$ \\
\hline $\mathrm{HC}$ & Hydrocarbons (ppm volume) \\
\hline $\mathrm{kW}$ & Kilowatt \\
\hline NOx & Nitrogen oxides (ppm) \\
\hline PM & Particulate matter \\
\hline ppm & Parts per million \\
\hline rpm & Revolution per minute \\
\hline
\end{tabular}

\section{INTRODUCTION}

Alcohols such as ethanol, methanol and butanol fuels have been widely studied and used in diesel engine. Recent advancements in production techniques have made butanol a cost effective and environmentally friendly alternative (Tashiro et al2007) ${ }^{1}$. Butanol is a good fuel additive for use in diesel engines with several advantages such as higher cetane number, high heating value, better miscibility with diesel and lower heat of vaporization (Lamani et al2017) ${ }^{2}$. It is easy to ship n-butanol in fuel pipelines, due to its low corrosive and low hydrophobic properties, also can be produced from both fossil matter and waste biomass with the same properties, also can be blended with diesel fuel without phase separation (Jang et al2012) ${ }^{3}$.

Many investigators compared emission and performance characteristics of $\mathrm{n}$ butanol/diesel blends fueled engine and net diesel fueled engine. Yusri et al(2019) ${ }^{4}$ noticed that $n$-butanol/diesel blends reduce rate of pressure rise and rate of heat release, increase both ignition delay and burn duration, increase engine cyclic 
variations, reduce NOx, CO and HC. Siva et al $(2019)^{5}$ reported that n-butanol/diesel blends reduced CO, NOx, BSFC and smoke emissions, increased both HC and BTE. They used simulation studies of piston bowl geometry to decrease the HC emission.

Xinling et al (2019) $)^{6}$ evaluated four alcohols, ethanol, n-butanol, iso-butanol, and npentanol with the same oxygen contenton a diesel engine. They reported that; (i) in comparison with diesel, the alcohol blends have higher peak heat release rate, longer ignition delay, and shorter combustion duration. (ii) All blends showed similar organic carbon emissions and a slight variation or no significant change in regulated gaseous emissions (CO, $\mathrm{HC}, \mathrm{NOx})$ at different loads.

Dev et al (2018) ${ }^{7}$ used various blends of n-butanol/diesel to study a single-cylinder 4stroke diesel genset engine. Results showed that; blends were better for CO, NOx, smoke, noise and vibration however, the same may not be said for hydrocarbon emissions and engine efficiency. Nurun et al $(2017)^{8}{ }^{8}$ investigated that the $\mathrm{n}$ butanol/diesel blends under the European Stationary Cycle (ESC)reduce power, peak pressure, particulate matter $(\mathrm{PM})$ and particle number (PN) emissions as well as increase BSFC, exhaust blow-by, HC, NOx emissions.

Venkatesh et al (2017) ${ }^{9}$ reported reduction of smoke opacity, NOx and carbon monoxide emissions with the increasing n-butanol percentage in diesel fuel. Ashish et al $(2017)^{10}$ reported that $n$-butanol/diesel blends reduce smoke, NOx, $\mathrm{CO}$ and engine performance as well as increase $\mathrm{CO} 2$ and HC. Zhang et al (2016) ${ }^{11}$ conducted an experimental study on the influence of using the effect of n-butanol/diesel blends on particle emissions of diesel engine and indicated that the concentration of total particle emissions reduces.

Ibrahim et al (2016) ${ }^{12}$ observed that the blending of $20 \%$ n-butanol/diesel blend resulted in significant reduction in PM with a negligible change in engine performance. Zheng et al (2015) $)^{13}$ reported that when neat n-butanol was injected in a diesel engine, the emissions of $\mathrm{NO}_{\mathrm{x}}$ and smoke reduced substantially but $\mathrm{HC}$ and $\mathrm{CO}$ emissions were increased. Sahin et al (2015) ${ }^{14}$ investigated experimentally that; maximum smoke reduction of $21.75 \%$ was observed with $4 \%$ n-butanol blend, and maximum NOx reduction of $5.03 \%$ was observed for $2 \%$ n-butanol blend.

Choi et al (2015) $)^{15}$ showed that; (i) Blending of n-butanol should be equal to or less than $10 \%$ for reduced emissions. (ii) For B5 and B10, PM size under $50 \mathrm{~nm}$ is reduced to 18.5 and $31.1 \%$, respectively, whereas for B20 it increased to $20.5 \%$. (iii) On a positive note, these blends have resulted in improved engine performance. Zehra et al $(2015)^{16}$ investigated the effects of the using of low ratio n-butanol/diesel fuel blends on a diesel engine. The test results showed that engine characteristics and NOx emission improve for $\mathrm{nB} 2$ and $\mathrm{nB} 4$ at selected engine speeds and loads. However, they 
deteriorate for $\mathrm{nB} 6$. At the end, $\mathrm{nB} 2$ was determined as the most favorite blend for engine characteristics and NOx. Smoke reduce for $\mathrm{nB} 2, \mathrm{nB} 4$ and $\mathrm{nB} 6$ at all of the selected engine speeds.

Huang et al (2015) ${ }^{17}$ concluded that BSFC increase and BTE decreases. However, variations in BSFC and BTE also depend on base fuel and operating parameters. Also, reduce smoke significantly, reduces $\mathrm{CO}$, reduce $\mathrm{NO}_{\mathrm{x}}$ marginally, and increase HC.Sahin et al (2015) ${ }^{18}$ investigated experimentally that; maximum smoke reduction of $21.75 \%$ was observed with $4 \%$ butanol/diesel blends, and maximum NOx reduction of $5.03 \%$ was observed for $2 \%$ n-butanol blend.

\section{1 Current Research}

According to the above literature review and authors' best knowledge, the simultaneously characteristics evaluations of diesel engine generators are rather limited. As is known, these engines are noisy, generate vibrations, and pollute air so, there is more pressing need to explore and compare these simultaneously characteristics when working with net diesel and other fuel blends which, could be alternatives for new as well as old engines without structural modifications.

For that purpose, in this study tests were carried out using three of n-butanol/diesel blends on volume bases with concentrations of 5,10 and $15 \%$, identified as nBu5, $\mathrm{nBu} 10$ and $\mathrm{nBu} 15$.

\section{MATERIALS and METHODOLOGY}

Three different $\mathrm{nBu} / \mathrm{DF}$ blends having $5 \% \mathrm{nBu}$ with $95 \%$ reference diesel (DF), $10 \%$ $\mathrm{nBu}$ with $90 \% \mathrm{DF}$ and $15 \% \mathrm{nBu}$ with $85 \% \mathrm{DF}$, identified as $\mathrm{nBu} 5, \mathrm{nBu} 10$ and $\mathrm{nBu} 15$, denoted as $\mathrm{nBu} 5, \mathrm{nBu} 10$ and $\mathrm{nBu} 15$. Properties of $\mathrm{n}$-butanol are listed in Table 1 together with the Egyptian diesel specifications (Ahmed et al 2019) ${ }^{19}$.

\section{Table 1}

Properties of n-butanol and Egyptian diesel fuel

\begin{tabular}{|l|l|l|}
\hline property & Diesel & n-Butanol \\
\hline Specific gravity at $15.56^{\circ} \mathrm{C}$ Density $\left(\mathrm{kg} / \mathrm{m}^{3}\right)$ & $840^{\mathbf{b}}$ & $810^{\mathrm{a}}$ \\
\hline Latent heat of evaporation $(\mathrm{MJ} / \mathrm{kg})$ & 0.27 & 0.43 \\
\hline Calorific value $(\mathrm{kJ} / \mathrm{kg})$ & Min $42.7^{\mathbf{b}}$ & $33.1^{\mathbf{a}}$ \\
\hline Cetane index & $55.6^{\mathbf{b}}$ & $25^{\mathbf{a}}$ \\
\hline Boiling point $\left({ }^{\circ} \mathrm{C}\right)$ & $187-343$ & 117 \\
\hline Kinematic Viscosity @ 40_C & $3.21^{\mathbf{b}}$ & $2.22^{\mathrm{a}}$ \\
\hline
\end{tabular}

${ }^{\mathrm{a}}$ Data have been provided by the supplier specification

b Data have been provided by the Egyptian diesel fuel 


\section{1 Measured and Computed Parameters}

Total noise, $\mathrm{CO}_{2}, \mathrm{NO}_{\mathrm{X}}, \mathrm{CO}, \mathrm{HC}$ and EGT of each test blend were measured. The engine block top RMS vibration ( $\mathrm{g}$ ), fuel consumption (FC), BSFC, BTE, \%, CV and $\mathrm{CN}$ were computed according to the following equations (Ashish et al 2017) ${ }^{20}$.

$g_{\text {total }}=\sqrt{g_{x}^{2}+g_{y}^{2}+g_{z}^{2}}$

Where; $g_{x, y, z}=$ vibration for vertical, lateral, longitudinal direction respectively

$g_{\text {total }}=$ total acceleration of engine vibration

$\mathrm{FC}=\frac{3600 \rho \mathrm{m}}{1000 \mathrm{~kg}} \frac{\mathrm{kg}}{\mathrm{hr}} 2$

$\rho=$ density of fuel in gram/cc, $\mathrm{m}=$ burette reading in $\mathrm{cm}^{3}, \mathrm{~T}=$ time taken in seconds.

$\mathrm{BSFC}=\quad \frac{\mathrm{FC}}{\mathrm{P}} \frac{\mathrm{kg}}{\mathrm{kWhr}}$

$\mathrm{P}$ is the output power in $\mathrm{kW}$

$\mathrm{BTE} \%=\frac{3600 \mathrm{P}}{\mathrm{FC} C V}$

$\mathrm{CV}$ of blends $=\frac{\left(\rho_{n B u} \mathrm{CV} n B u \frac{\mathrm{v}_{n B u}}{\mathrm{~V}}\right)+\left(\rho_{\mathrm{DF}} \mathrm{CV} \mathrm{DF}_{\mathrm{DF}} \frac{\mathrm{V}_{\mathrm{DF}}}{\mathrm{V}}\right)}{\left(\rho_{n B u} \frac{\mathrm{V}_{n B u}}{\mathrm{~V}}\right)+\left(\rho_{\mathrm{DF}} \frac{\mathrm{V}_{\mathrm{DF}}}{\mathrm{V}}\right)} \frac{\mathrm{kj}}{\mathrm{kg}}$

$\rho$ density, $\rho_{\mathrm{nBu}, \mathrm{DF}}$ density of butanol and diesel respectively

$\mathrm{CV}$. calorific value, $\mathrm{CV}{ }_{\mathrm{nBu}, \mathrm{d}}$ the $\mathrm{CV}$ of butanol and diesel respectively

$\mathrm{V}$. total volume of blend, $\mathrm{V}_{\mathrm{nBu}, \mathrm{d}}$ volume ratio of butanol and diesel respectively

$\mathrm{CN}=\mathrm{CN}_{n B u} \frac{\mathrm{V}_{n B u}}{\mathrm{~V}}+\mathrm{CN}_{\mathrm{DF}} \frac{\mathrm{V}_{\mathrm{DF}}}{\mathrm{V}}$

$\mathrm{CN}{ }_{n B u, D F}$ is cetane number of butanol and diesel respectively

Fuel Blends properties and calculations are listed in Table 2.

\section{Table 2}

Fuel Blends and its Properties Calculation

\begin{tabular}{|l|l|l|l|l|}
\hline $\begin{array}{l}\text { Fuel blend } \\
\text { in vol. }\end{array}$ & $\begin{array}{l}\text { Diesel } \\
(\% \mathrm{v} / \mathrm{v})\end{array}$ & n-butanol & $\begin{array}{l}\text { Cetane } \\
\text { Number }^{\mathrm{a}}\end{array}$ & Calorific value $^{\mathrm{b}}$ \\
\hline Diesel fuel & 100 & - & 55.00 & 44.30 \\
nBu5 & 95 & 5 & 53.50 & 43.76 \\
nBu10 & 90 & 10 & 52.00 & 43.21 \\
nBu15 & 85 & 15 & 50.50 & 42.67 \\
\hline
\end{tabular}

${ }^{\mathrm{a}, \mathrm{b}}$ Data have been computed by Ref. (20) 


\section{2 Engine Under Study}

The technical specifications of genset engine are given in Table 3 and layout of the test bed constructed in the automotive laboratory, faculty of engineering, Minia University, Figure 1.

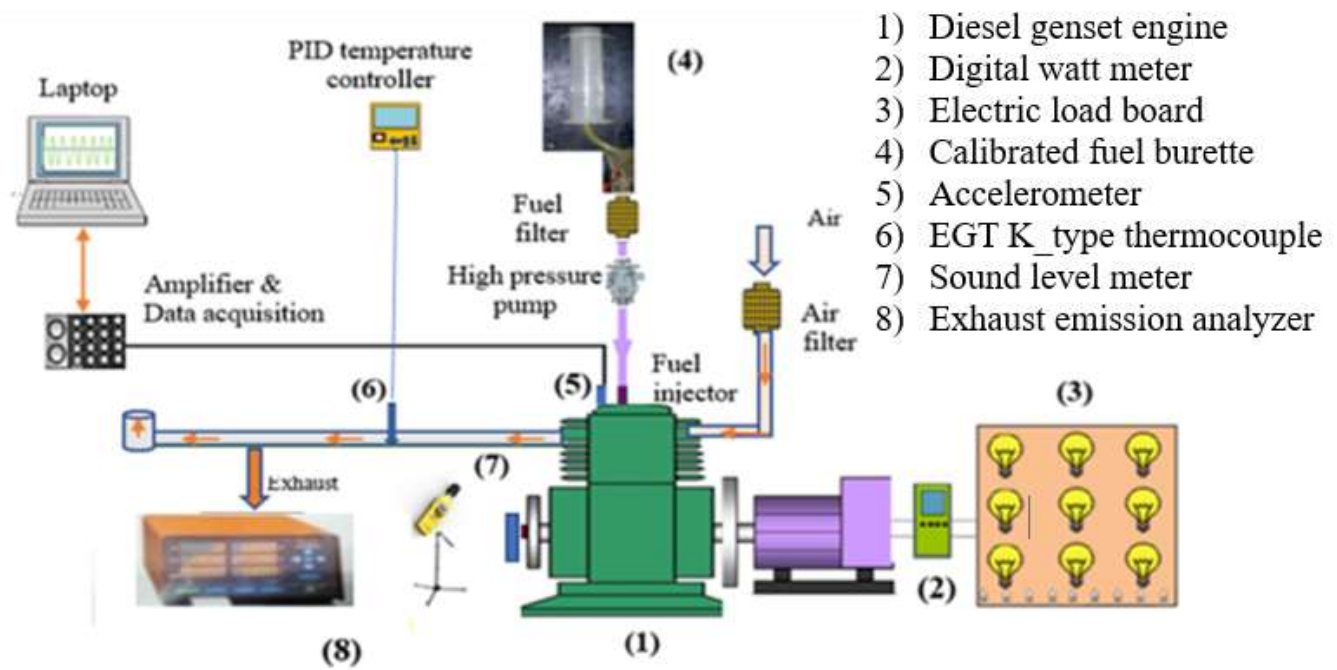

Fig. 1. A schematic diagram of experimental setup.

Table 3

Specifications for lister generator, Model GF-KM3

\begin{tabular}{|l|l|}
\hline Type & $\begin{array}{l}\text { Single cylinder, } \\
\text { strokes, air cooled }\end{array}$ \\
\hline Bore x stroke & $86 \times 70 \mathrm{~mm}$ \\
\hline Displacement & $406 \mathrm{~cm} 3$ \\
\hline Max. Output Power & $9.0 / 3000 \mathrm{hp} / \mathrm{rpm}$ \\
\hline Rated voltage & $220 \mathrm{v}$ \\
\hline Rated Frequency & $50 \mathrm{~Hz}$ \\
\hline Rated Output & $5000 \mathrm{~W}$ \\
\hline Max. Output Power & $5500 \mathrm{~W}$ \\
\hline
\end{tabular}

\section{3 Measured Instruments}

Total noise of engine is measured by $\mathrm{B} \& \mathrm{~K}$ sound level meter, engine vibration is measured by $\mathrm{B} \& \mathrm{~K}$ accelerometer, $\mathrm{CO}, \mathrm{CO}_{2}, \mathrm{HC}$ and $\mathrm{NO}_{\mathrm{X}}$ is measured by an exhaust emission analyzer model - GA4000XD, EGT is measured by $\mathrm{K}$ type thermocouple and fuel consumption is measured by a calibrated fuel burette with a valve.

\section{4 Error Analysis}

The uncertainty range of BSFC and BTE comes from the errors in the measurement of FC, brake power and calorific value. Accuracy of instruments are shown in Table 4. 


\section{Table 4}

Description and accuracy of instruments

\begin{tabular}{|l|l|l|}
\hline Sensor/type & Description & Accuracy \\
\hline Digital thermometer & EGT & $\pm 0.1^{\circ} \mathrm{C}$ \\
\hline Accelerometer & Vibration & $0.3 \%$ \\
\hline Sound level meter & Noise & $0.2 \mathrm{~dB}$ \\
\hline Emission analyzer & Exhaust gases & $\begin{array}{l}\mathrm{CO} \pm 0.01 \%, \mathrm{CO}_{2} \pm 0.1 \% \\
\mathrm{NOx} \pm 1 \mathrm{ppm}, \mathrm{HC} \pm 1 \mathrm{ppm}\end{array}$ \\
\hline
\end{tabular}

\section{5 Experimental Precautions}

The blends mixing were not at rate cause turbulence or bubbles. The thermocouple and analyzer gas sampling probe are placed in fixed position. The engine was warmed up. The first tests were carried out using diesel fuel at different loads and rated speed 3000 rpm then, the rest of the tests were carried out using all the fuel blends under the same conditions. Before running the engine to another fuel, it was permitted to keep running to consume the rest of fuel from the past experiment. For each test, three readings were taken to increase confidence.

\section{RESULTS AND DISCUSSION 3.1 Variation of Engine Body Vibration}

The top of engine block is the highest sensitivity place to vibrations derived from combustion process and the lowest sensitivity place to vibrations derived from mechanical parts, thus the accelerometer is placed on the engine cylinder head cover to measure the vibration resulted of combustion process(Chiati et al 2014) $)^{21}$. The vibration

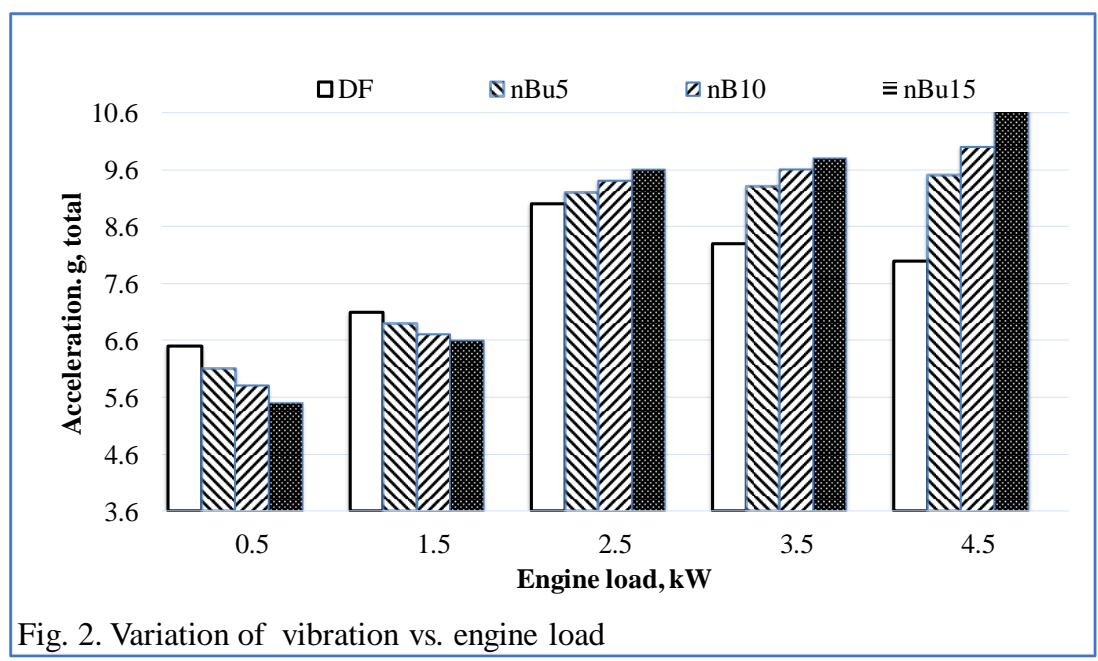
measured for three directions, vertical $(\mathrm{x})$, lateral $(\mathrm{y})$, and longitudinal $(\mathrm{z})$. The resultant ( $\left.\mathrm{g}_{\text {Total }}\right)$ was computed, according to:

$g_{\text {total }}=\sqrt{g_{x}^{2}+g_{y}^{2}+g_{z}^{2}}$

Fig. 2 showed at different engine loads, the effect of diesel and $n$-butanol/diesel blends on engine vibration.

The results show that; At lower engine load, both the total vibration level of diesel and diesel/n-butanol blends rapidly increase with increasing engine load but, 
during this diesel produces highest vibration level and diesel/n-butanol blends burn smoothly and produce less vibration due to both its inherent fuel oxygen content and lean fuel-air mixture. At higher engine load, diesel vibration level does not show a significant increase but, diesel/n-butanol blends start generating higher vibration. The reasons may be that, fuel-air mixture becomes richer in high loads, so the effect of lower fuel viscosity of diesel/n-butanol blends becomes significant and increase the ignition delay and cancel the moderating effect of inherent fuel oxygen content. Consequently, the vibration level continues to rise, albeit slowly, even further due to the amount of fuel injected leading to higher cylinder pressures.

\section{2 Variation of Noise Emission}

Fig. 3 showed at different engine loads, the effect of diesel and $n$-butanol/diesel blends on total noise.The results show that; At lower engine load, both the total noise level of diesel and diesel/n-butanol blends rapidly increase with increasing engine load but, diesel produces highest combustion noise and diesel/n-butanol blends burn smoothly and produce less noise due to both its inherent fuel oxygen content and lean fuel-air mixture. At higher engine load, diesel combustion noise level does not show a significant increase but, diesel/n-butanol blends start generating higher combustion noise and become the noisiest at $100 \%$ engine load. The reasons behind that, fuel-air mixture becomes richer, so the effect of lower fuel viscosity of diesel/nbutanol blends become significant and increase the ignition delay and cancel the moderating effect of inherent fuel



Fig. 3. Variation of noise vs. engine load oxygen content. Consequently, the noise level continues to rise, albeit slowly, even further due to the amount of fuel injected leading to higher cylinder pressures.

\section{3 Variation of BSFC}

Fig. 4 shows at different engine loads, the effect of diesel and n-butanol/diesel blends on BSFC.The results show that; Irrespective of fuel used, due to the very large ratio of frictional losses to the brake power at low engine loads, BSFC consumption is greater and due to incomplete combustion at high engine loads, BSFC increase. Adding 
butanol to diesel increase BSFC consumption and increase more with butanol addition to diesel, itmay be due to lower heating value of butanol (Atmanli et al 2015) ${ }^{22}$ and lower cetane number which lead to ignition delay increase and therefor fuel increase before combustion. Like it, the time duration of combustion at higher temperature increase and heat transfer to engine parts increases, the effective energy conversion into brake power decreases.



\section{4 Variation of Brake thermal efficiency (BTE)}

Fig. 5 shows variation of brake thermal efficiency for all test fuels at varying engine loads. Fig. 5 shows at different engine loads, the effect of diesel and n-butanol/diesel blends on BTE. The results show that; Irrespective of fuel used, at low loads BTE reduce due to low BMEP, which degrades the combustibility of fuel then BTE, increase as a result of good combustion then BTE, decrease due to bad fuel utilization (Emiroğlu et al 2018) ${ }^{23}$. Adding butanol to diesel

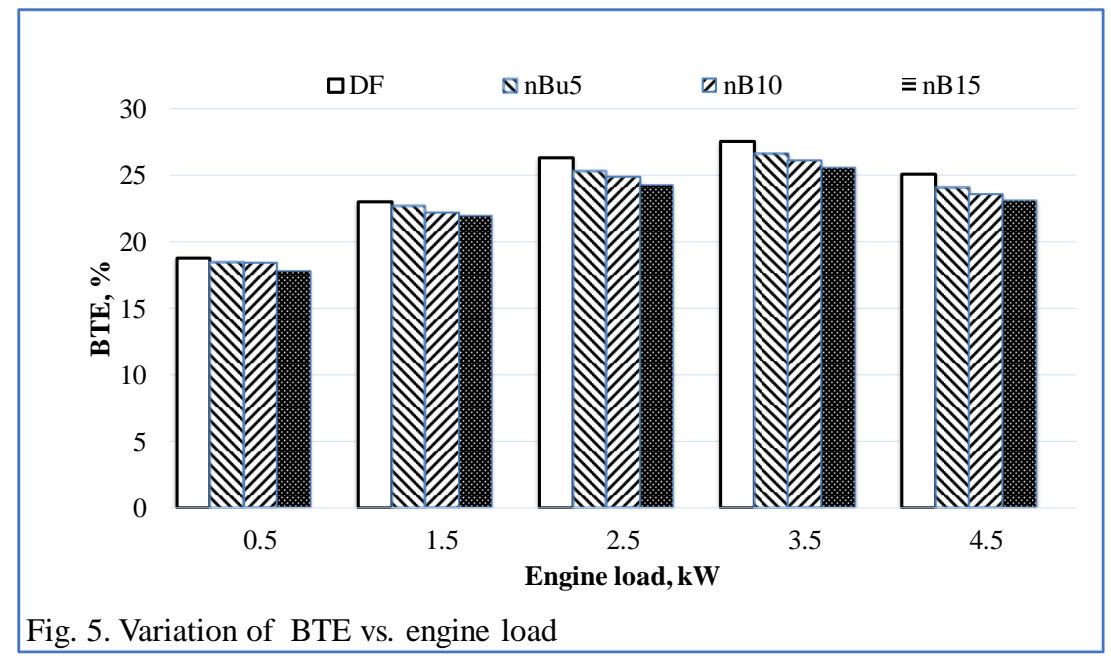
reduce BTE emission and reduce more with butanol addition, it may be due to release more heat in the expansion stroke due to delayed combustion resulted from low $\mathrm{CN}$, high latent heat vaporization and low calorific value of butanol.

\section{5 Variation of EGT}

Fig. 6 shows at different engine loads, the effect of $n$-butanol/diesel blends on EGT. The results show that; Irrespective of fuel used, EGT increased with increasing engine 
load, this is attributed to combustion of maximum amount of fuel at highest engine load. Adding butanol to diesel reduce EGT emission and reduce more with butanol addition, it may be due to; Oxygen content enhances leanerand cooler combustion.Higher latent heat of vaporization of $n$ butanol reduce peak Fig. 4. Variation of EGT vs. engine load cylinder temperature, which in turn reduce EGT(Işık MZ et al 2017) ${ }^{24}$.

\section{6 Variation of Nitrogen oxides (NOx)}

$\mathrm{NO}_{\mathrm{X}}$ formation is mainly influenced by oxygen content, in-cylinder temperature, and reactions (palash et al 2013) ${ }^{25}$. Fig. 7 shows at different engine loads, the effect of diesel and $\mathrm{n}$ butanol/diesel blends on NOx. The results show that; Irrespective of fuel used oxides of nitrogen increase with engine load due to higher combustion temperature. Adding butanol to diesel reduce NOx emission and reduce more with butanol addition, due to the leaner engine running and the temperature lowering effect of the butanol, due to its lower calorific value and its higher heat of evaporation. Similar trends were found in Miers et al $(2008)^{26}$.
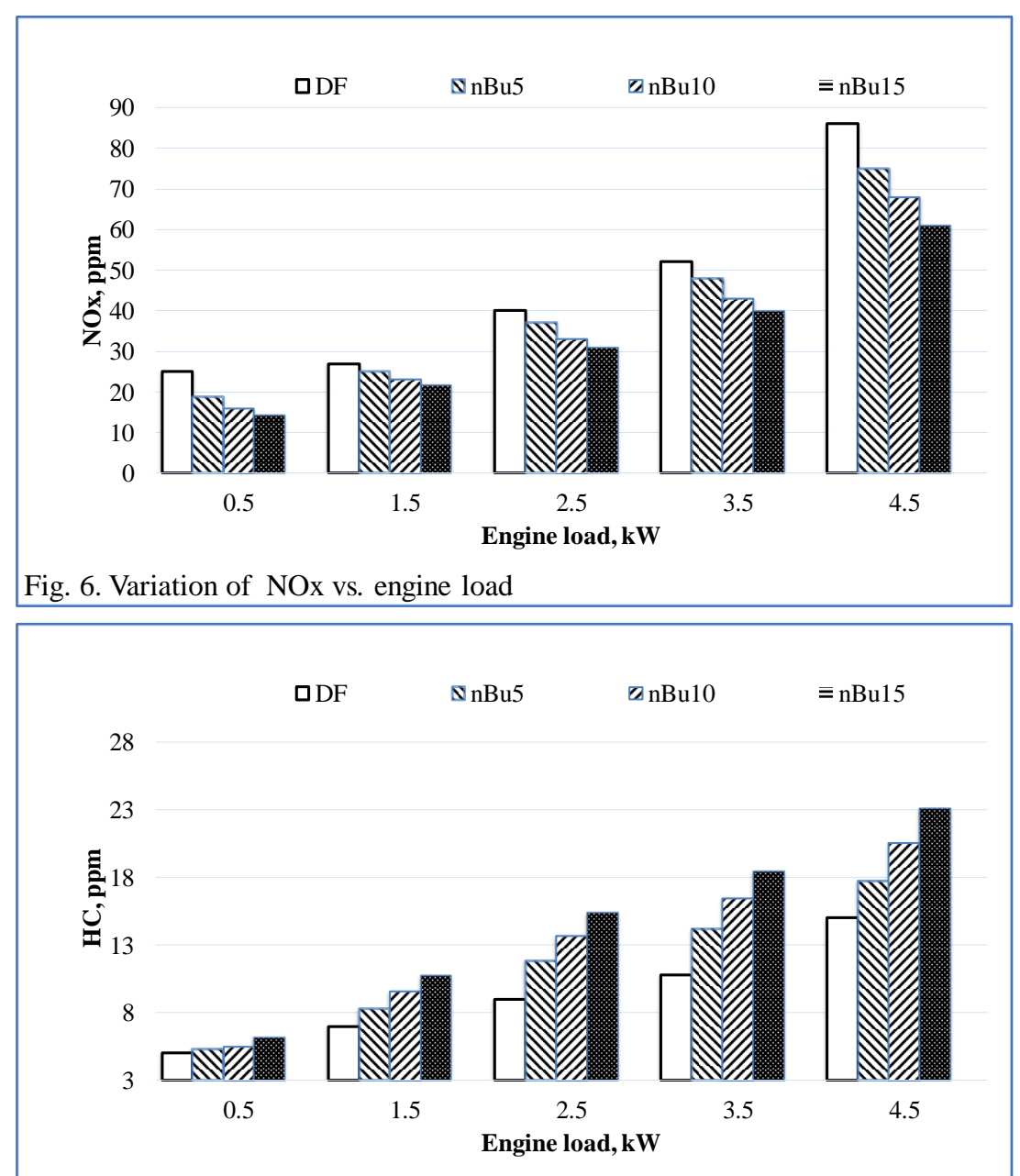

Fig. 7. Variation of $\mathrm{HC}$ vs. engine load 


\section{7 Variation of Hydrocarbons (HC)}

Fig. 8 shows at different engine loads, the effect of diesel and $n$-butanol/diesel blends on HC. Irrespective of fuel used at low loads HC decrease but increase at high loads due to less oxygen and more fuel (Kalam et al 2011) ${ }^{27}$. Adding butanol to diesel increase $\mathrm{HC}$ emission and increase more with butanol addition, thistrend may be due to; (i) Lower cetane number and delay the ignition timing which disturb the combustion.(ii) The higher heat of butanol evaporation (Racopoulus et al 2010) ${ }^{28}$.

\section{8 Variation of $\mathrm{CO}$}

Fig. 9 showed at different engine loads, the effect of diesel and n-butanol/diesel blends on CO.The results show that;Irrespective of fuel used, $\mathrm{CO}$ increase as the engine load increase due to the unstable combustion. Adding butanol to diesel reduce $\mathrm{CO}$ and reduce more with butanol addition. This trend may be due to the higher oxygen content of blends which, enhance

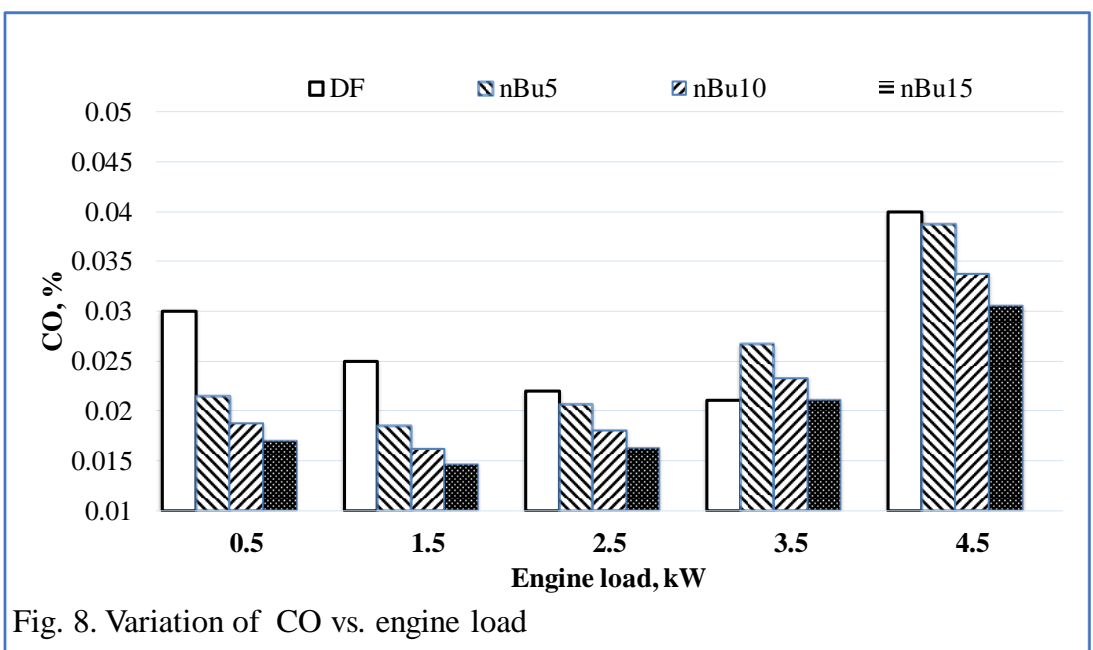
the complete combustion(Yao et al 2010) ${ }^{29}$.

\section{9 Variation of $\mathrm{CO2}$}

Fig. 10 shows at different engine loads, the effect of diesel and n-butanol/diesel blends on $\mathrm{CO}_{2}$. The results show that;D100 produced higher $\mathrm{CO}_{2}$ compared to all the blended fuels. Adding butanol to diesel increase $\mathrm{CO}_{2}$ and

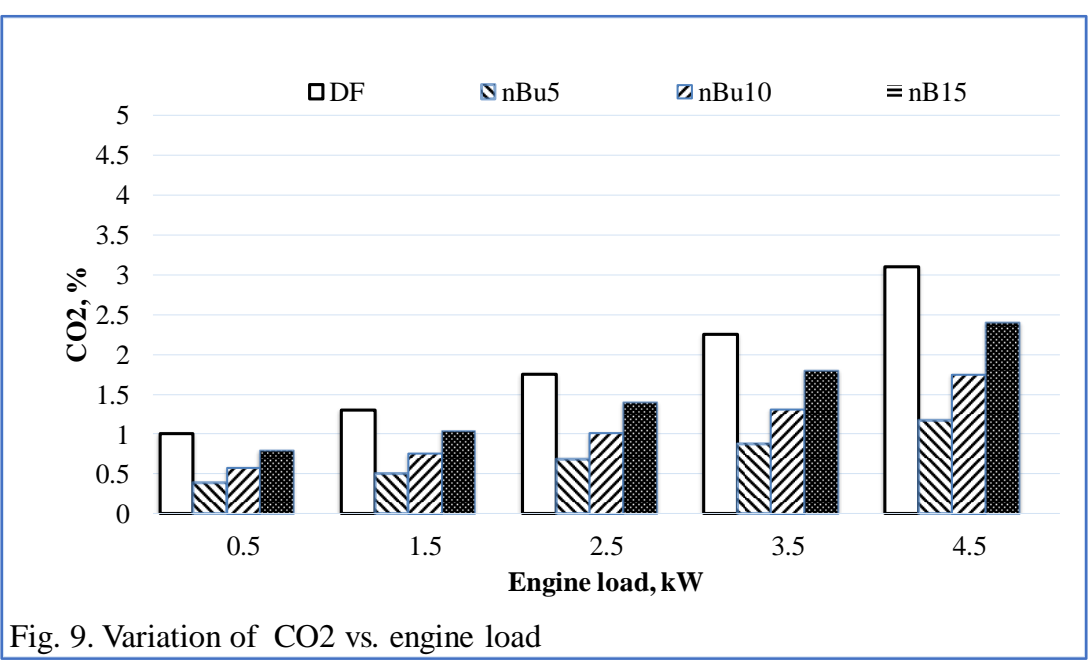

Fig. 9. Variation of $\mathrm{CO} 2$ vs. engine load 
increase more with butanol addition, due to the engine operating at a leaner air-fuel mixture. This finding is inagreement with Jeevahan et al $(2018)^{30}$ which attributed that to the butanol being an oxygenated additive that turns $\mathrm{CO}$ into $\mathrm{CO}_{2}$ exhaust emissions.

\section{Conclusions}

An experimental investigation was conducted to evaluate the use of n-butanol as supplement to the conventional diesel fuel at blending ratios of 5/95, 10/90 and $15 / 85$ (by volume) in a diesel genset engine. The series of tests were conducted using each of the above fuel blends, with the engine working at a constant speed of $3000 \mathrm{rpm}$ and five different loads. When working with neat diesel or fuel blends measurements of total noise from the engine, cylinder block vibrations, emissions (NOx, HC, CO, EGT) and fuel consumption were made at the same conditions. BSFC and BTE were computed. The following conclusions can bedrawn with n-butanol/diesel fuel blends against diesel fuel; (i) According to engine performance test results; a little higher specific fuel consumption was observed with corresponding slight increase of brake thermal efficiency and little lower exhaust gas temperatures. (ii) According to engine emission test results; the NOx was slightly reduced, this reduction being higher the higher the percentage of butanol in the blend. The $\mathrm{CO}$ emissions were reduced, on the contrary, $\mathrm{HC}$ emissions were increased, this increase being higher the higher the percentage of butanol in the blend. (iii) According to engine vibration and noise test results; Noise and vibration characteristics are somewhat better especially at lesser loads.

\section{References}

${ }^{1}$ Tashiro, Y., Shinto, H., Hayashi, M., Baba, S.-i., Kobayashi, G., and Sonomoto, K., (2007). Novel high-efficient butanol production from butyrate by non-growing clostridium saccharoperbutylacetonicum n1-4 (atcc 13564) with methyl viologen. Journal of bioscience and bioengineering, 104(3):238-240.

${ }^{2}$ Lamani, VT., Yadav, AK., Kumar, GN., (2017a) "Effect of exhaust gas recirculation rate on performance, emission and combustion characteristics of common rail diesel engine fuelled with n-butanol-diesel blends. Biofuels", ttp://dx.doi.org/10.1080/17597269. 1369631.

3 Jang, YS., Malaviya, A., Cho, C., Lee, J., Lee, SY., (2012) "Butanol production from renewable biomass by clostridia", Bioresour Technol 123:653-663.

${ }^{4}$ I.M. Yusri, Rizalman Mamat, M.K. Akasyah, M.F. Jamlos, A.F. Yusop "Evaluation of engine combustion and exhaust emissions characteristics using diesel/butanol blended fuel" Applied Thermal Engineering 156 (2019) 209-219

${ }^{5}$ Siva, P., Rajesh, K., Srinivasa, R., Surapaneni, R., Ganji, "Effect of n-butanol/diesel blends and piston bowl geometry on combustion and emission characteristics of CI engine", Environmental Science and Pollution Research (2019) 26:1661-1674 
${ }^{6}$ Xinling Li, Chun Guan, Ke Yang, Chun Shun Cheung, Zhen Huang, "Impact of lower and higher alcohol additions to diesel on the combustion and emissions of a direct-injection diesel engine" Received: 17 November 2018 /Accepted: 25 April 2019 \# Springer-Verlag GmbH Germany, part of Springer Nature 2019

${ }^{7}$ Dev Prakash Satsangi and Nachiketa Tiwari (2018). "Experimental investigation on combustion, noise, vibrations, performance and emissions characteristics of diesel/n-butanol blends driven genset engine" Fuel 221 44-60.

${ }^{8}$ Md Nurun Nabi, Ali Zare, Farhad M. Hossain, Timothy A. Bodisco, Zoran D. Ristovski, Richard J. Brown, "A parametric study on engine performance and emissions with neat diesel and diesel-butanol blends in the 13-Mode European Stationary Cycle" Energy Conversion and Management 148 (2017) 251-259

9 Venkatesh Tavareppa Lamani, Ajay Kumar Yadav, Kumar Narayanappa Gottekere, "Performance, emission, and combustion characteristics of twin-cylinder common rail diesel engine fueled with butanol-diesel blends" Environ Sci Pollut Res (2017) 24:23351-23362

10 Ashish Nayyar, Dilip Sharma, Shyam Lal Soni and Alok Mathur (2017). "Experimental investigation of performance and emissions of a VCR diesel engine fuelled with n-butanol diesel blends under varying engine parameters" CrossMark, Environ Sci Pollut Res 24:2031520329

${ }^{11}$ Zhang, Z.H., Chua, S.M. and Balasubramanian, R. (2016). "Comparative evaluation of the effect of butanol-diesel and pentanol-diesel blends on carbonaceous particulate composition and particle number emissions from a diesel engine" Fuel 176: 40-47.

12 Ibrahim A. (2016). "Performance and combustion characteristics of a diesel engine fulled by butanol-biodiesel-diesel blends" Appl Therm Eng. 103:651-659.

${ }^{13}$ Zheng M, Li T, Han X. (2015). "Direct injection of neat $n$-butanol for enabling clean low temperature combustion in a modern diesel engine" Fuel 142:28-37.

${ }^{14}$ Sahin Z, Aksu ON (2015). "Experimental investigation of the effects of using low ratio nbutanol/diesel fuel blends on engine performance and exhaust emissions in a turbocharged DI diesel engine" Renew Energy 77:279-290

${ }^{15}$ Choi B, Jiang X, Kim YK et al (2015). "Effect of diesel fuel blend with nbutanol on the emission of a turbocharged common rail direct injection diesel engine" Appl Energy 46:2028.

${ }^{16}$ Zehra S, ahin and Orhan N. Aksu (2015). "Experimental investigation of the effects of using low ratio n-butanol/diesel fuel blends on engine performance and exhaust emissions in a turbocharged DI diesel engine" Renewable Energy 77 279-290

${ }^{17}$ Huang H, Liu Q, Yang R, Zhu T, Zhao R, Wang Y. (2015). "Investigation on the effects of pilot injection on low temperature combustion in high-speed diesel engine fueled with nbutanol-diesel blends" Energy Convers Manag 106:748-758.

${ }^{18}$ Sahin Z, Aksu ON (2015). "Experimental investigation of the effects of using low ratio nbutanol/diesel fuel blends on engine performance and exhaust emissions in a turbocharged DI diesel engine" Renew Energy 77:279-290

${ }^{19}$ Ahmed I. EL-Seesy, Hamdy Hassan and Hidenori Kosaka, "Improving the Performance of a Diesel Engine Operated with Jojoba Biodiesel-Diesel-n-Butanol Ternary Blends" Energy Procedia 156 (2019) 33-37 
${ }^{20}$ Ashish N., Dilip S., Shyam Lal Soni and Alok Mathur, "Experimental investigation of performance and emissions of a VCR diesel engine fueled with n-butanol diesel blends under varying engine parameters" Crossmark, Environ Sci Pollut Res, 2017; 24:20315-20329.

21 Chiatti G, Chiavola O, Recco E. "Combustion diagnosis via block vibration signal in common rail diesel engine”. Int J Eng Res 2014; 15:654-63.

${ }^{22}$ Atmanli A, Ileri E, Yuksel B, Yilmaz N (2015a) "Extensive analyses of diesel-vegetable oil-n-butanol ternary blends in a diesel engine" Appl Energy 145:155-162

${ }^{23}$ Emiroğlu AO, Şen M., "Combustion, performance and emission characteristics of various alcohol blends in a single cylinder diesel engine". Fuel 2018; 212:34-40.

${ }^{24}$ Işık MZ, Bayındır $\mathrm{H}$, İscan $\mathrm{B}$, Aydın $\mathrm{H}$. The effect of $\mathrm{n}$-butanol additive on low load combustion, performance and emissions of biodiesel-diesel blend in a heavy-duty diesel power generator. J Energy Inst 2017;90(2):174-84.

${ }^{25}$ Palash, S.M., Masjuki, H.H., Kalam, M.A., Masum, B.M., Sanjid, A., Abedin, M.J., "State of the art of NOx mitigation technologies and their effect on the performance and emission characteristics of biodiesel-fueled compression ignition engines". Energ. Convers. Manage. 2013; 76: 400-420.

${ }^{26}$ S.A. Miers, R.W. Carlson, S.S. McConnell, H.K. Ng, T. Wallner, J.L. Esper, Drive cycle analysis of butanol/diesel blends in a light-duty vehicle, SAE Technical Paper, 2008

27 Kalam, M.A., Masjuki, H.H., Jayed, M.H., Liaquat, A.M., "Emission and performance characteristics of an indirect ignition diesel engine fuelled with waste cooking oil. Energy 2011; 36: 397-402.

28 Rakopoulos DC, Rakopoulos DC, Hountalas DT, Kakaras EC, Giakoumis EG, Papagiannakis RG. Investigation of the performance and emissions of bus engine operating on butanol/diesel fuel blends. Fuel 2010;89(10):2781-90.

${ }^{29}$ [35] M. Yao, H. Wang, Z. Zheng, Y. Yue, Experimental study of n-butanol additive and multi-injection on HD diesel engine performance and emissions, Fuel 89 (2010) 2191-2201.

${ }^{30}$ J. Jeevahan, G. Britto Joseph, R. Durairaj, G. Mageshwaran, V. Sriram, Influence of diethyl ether on engine performance and emissions characteristics of blends of butanol, pentanol or biodiesel (neem oil methyl ester) in a single cylinder diesel engine, Int. J. Ambient Energy (2018) 1-9. 